\title{
Heidegger v Americe ${ }^{1}$
}

\section{Heidegger in America}

\author{
Ondřej Švec \\ Ústav filosofie a religionistiky \\ Filozofická fakulta \\ Univerzita Karlova v Praze \\ Nám. J. Palacha 2, 11638 Praha 1 \\ ondrej.svec@ff.cuni.cz
}

\begin{abstract}
Abstrakt/Abstract
Článek je věnován odůvodnění, projasnění a také kritickému zhodnocení poněkud zkratkovitého hesla o ,primátu praxe“, který v očích mnoha amerických interpretů představuje společného jmenovatele Heideggerova díla a pragmatismu v širokém slova smyslu. V mém podání nesměřuje Heideggerův důraz na praxi ani tak k převrácení tradiční hierarchie, podle níž svět nejprve poznáváme, abychom v něm mohli jednat, ale spíše $\mathrm{k}$ přehodnocení ontologického rámce, $\mathrm{v}$ němž byla otázka ohledně přednosti teorie či praxe až dosud kladena. V druhé části proto ukážu, jak Heideggerovo osobité pojetí praxe souvisí s jeho revizí bytí věcí a nás samotných, a podám důvody, proč na rozdíl od Dreyfusova, Okrentova a Blattnerova vymezení primátu praxe odmítám chápat veškerou srozumitelnost lidského života a světa jako něco odvozeného z našeho každodenního, praktického obstarávání.
\end{abstract}

This paper aims to justify, elucidate and critically assess a rather elliptical slogan ,about the primacy of practice“, which represents in the eyes of many American interpreters the common denominator of Heideggerian phenomenology and pragmatism in a broad sense of the term. From my perspective, Heidegger's insistence on the primordial practical association with things is not to be understood as an inversion of the traditional hierarchy, according to which we have to know the world prior to acting upon it, but rather as an integral part of his attempt to rebuild the ontological framework, in which the question of primary practice or theory used to be formulated. I will then show the connection between Heidegger's original account of practice and his intention to revise both the notion of the "things themselves" and the notion of the entity that we ourselves are. Finally, I will justify my reluctance towards the claim common to Dreyfus', Okrent's and Blattner's interpretations, according to which the intelligibility of both human life and world is to be understood as something derivative from our everyday coping with the surrounding world.

\footnotetext{
${ }^{1}$ Tento článek vznikl za podpory grantového projektu GA ČR „Pragmatický obrat ve fenomenologii“ (GA14-07043S).
} 
Cum grano salis lze říci, že americká recepce Heideggera se od původního zamítavého postoje, inspirovaného logickým positivismem, přes misionářské období ${ }^{2}$ a prvotní snahy o věrnou interpretaci a erudovanou rekonstrukci Heideggerových argumentů, zahrnující i první významné překlady v 50. a 60. letech, posunula až k osobité formě emancipace, která se od počátku 70. let nezdráhá zacházet s Heideggerovým odkazem volněji, tj. méně exegeticky a nezřídka synkreticky, a která se vyznačuje osobitým důrazem na primát praxe jako východiska pro revizi tradičních epistemologických i ontologických předpokladů. V přednáškách H. Dreyfuse na Kalifornské univerzitě v Berkeley se Heideggerovo pojetí bytíve-světě nejprve stává vítanou alternativou vůči převážně scientistické orientaci analytické filosofie a příležitostí ke zpochybnění reprezentacionalistických východisek soudobé epistemologie a filosofie mysli. Na sklonku 70. let se pak Heidegger v reinterpretaci Richarda Rortyho ocitá v těsné blízkosti jak Deweyho kritiky divácké teorie poznání, tak i pragmatismu v široce chápaném smyslu. Odhalování pragmatických momentů v Heideggerově díle a rozvedení teze o přednosti praktického zvládání [knowing how] před nezaujatým teoretickým výkladem [knowing that] se nakonec přetvárí ve specifický obor zkoumání, na němž se podílí široká skupina Dreyfusových spolupracovníků (J. Haugeland, M. Okrent) a žáků (M. Wrathall, W. Blattner, S. Crowell) a který rozvíjejí také práce filosofů navazujících na Rortyho (R. Brandom). S ohledem na tento kontext směřuje hlavní záměr předložené stati $\mathrm{k}$ projasnění poněkud zkratkovitého hesla o ,primátu praxe“, který v očích výše uvedených interpretů představuje společného jmenovatele mezi Heideggerovou fenomenologií a pragmaticky orientovanou částí post-analytické filosofie. Tato konfrontace zároveň směřuje k detailnější analýze vztahu mezi praktickým pohroužením do věcí na straně jedné a jejich objektivizující tematizací na straně druhé. Za tímto cílem bude třeba odlišit epistemologický a ontologický význam Heideggerova prohlášení, podle nějž se s věcmi nejprve setkáváme jako s pragmaty, a nikoli jako s předměty charakterizovanými svými konstatovatelnými vlastnostmi. Na jedné straně jde bezpochyby o epistemologický primát praktického porozumění vůči nezaujatému pohledu či teoretickému výkladu, který H. Dreyfus charakterizuje slovy: „Situované užívání prostředků je v nějakém smyslu prvotní vůči pouhému pohlížení na věci. “3 Ještě než však odhalíme, v jakém konkrétním smyslu lze tuto prvořadost chápat, je třeba na straně druhé předejmout, že Heideggerovi ani zdaleka nejde o revizi převládajícího modelu „teorie poznání“, ale o vypracování nové ontologie, v jejímž rámci je „to, co je odhaleno zacházením, ontologicky základnější, než jsou substance s jejich určitými a na kontextu nezávislými vlastnostmi.“4

\footnotetext{
${ }^{2}$ Tento termín nevolím nahodile, nebot' první recepce a překlady Heideggera v Americe vznikají skutečně na teologických, převážně katolických katedrách a první překlady jeho děl u Harper \& Row vycházejí v kolekci „Religious Perspectives“vedle děl Karla Jasperse či Paula Tillicha.

${ }^{3}$ Dreyfus (1991, s. 61).

${ }^{4}$ Tamtéž.
} 


\section{Primát praxe jako epistemologická teze}

Jak bylo naznačeno v úvodu, většina nejvlivnějších amerických interpretů, počínaje $\mathrm{H}$. Dreyfusem, přes M. Okrenta, R. Rortyho a W. Blattnera až po R. Brandoma zdůrazňuje jako jeden z nejvýznamnějších motivů 1. oddílu Bytí a času ,primát praxe“ [primacy of practice], jejž např. W. Blattner shrnuje jako epistemologickou tezi, „podle níž rozumnost a srozumitelnost lidského života spočívá primárně v před-kognitivní praxi a podle níž je poznání něčím odvozeným vưči této praxi.“5 Touto prvořadou praxí míní interpreti zejména to, co sám Heidegger nazývá „obstarávajícím zacházením“ [Besorgende Umgang], „které něčím manipuluje a něco používá a které má svůj vlastní způsob ,poznání““6 a pro něž $\mathrm{v}$ témže paragrafu uvádí $\mathrm{v}$ závorce řecký termín $\pi \rho \tilde{\alpha} \xi 1 \zeta$, jako by se jednalo o synonyma. Jak dále plyne z výše uvedené citace, toto obstarávající zacházení s věcmi není a-teoretické ve smyslu, že by postrádalo vidění a rozumění, nýbrž disponuje svým vlastním způsobem pohlîžení, který Heidegger nazývá praktický ohled [Umsicht] a který předchází každé možnosti něco poznat $\mathrm{v}$ jeho vlastnostech.

Tento praktický ohled se přesto od teoretického výkladu liší za prvé tím, že netematizuje a nezpředmětňuje, nebot' se chápe věcí ve světle úkolu, jenž má být vykonán. Ve známém Heideggerově příkladu je kladivo právě takovou věcí, s níž se primárně nesetkáváme jako s tematizovaným předmětem, tj. objektem poznatelným $v$ jeho vlastnostech, ale jako s prostředkem „k něčemu“. Chopit se kladiva neznamená vypozorovat $\mathrm{z}$ jeho konstatovatelných vlastností, že by se tím daly zatlouct hřebíky.

„Čím méně kladivo pouze okukujeme, tím zručněji je používáme, tím původnější je náš vztah k němu a tím nejzastř̌eněji se s ním setkáváme jako s tím, čím je, totiž kladivem." ${ }^{\text {"7 }}$

Tento Heideggerův příklad je citován všemi pragmaticky orientovanými komentátory právě proto, že odhaluje praktické chování jako původnější vrstvu přístupu k věcem: praktické odhalení věcí v jejich vhodnosti a nevhodnosti pro daný úkol předchází zpředmětňujícímu postoji ke světu, který je pouze odvozeným modem našeho pohrouženého, netematického zacházení s věcmi. ${ }^{8}$

Pro vykázání pragmatické teze, podle níž je teoretické pojímání něčím odvozeným či přímo parazitujícím na prakticky orientovaném porozumění, však nestačí doložit, že se nám věci zprvu odhalují ve své služebnosti, vhodnosti či nevhodnosti k jisté praxi, ale je třeba také

\footnotetext{
${ }^{5}$ Blattner (2007, s. 17).

${ }^{6}$ Heidegger (1996, s. 87).

${ }^{7}$ Tamtéž, s. 89.

${ }^{8}$ Srov. interpretaci tohoto př́kladu jako prokazujícího primát know-how vůči know-that u H. Dreyfuse: „rozumět kladivu neznamená vědět, že kladiva mají takové a takové vlastnosti a že slouží k jistým účelům - nebo že za účelem zatloukání je třeba dodržovat jistý postup, např́klad uchopit kladivo do ruky atd. Rozumět kladivu znamená na nejzákladnější rovině spíše vědět, jak zatloukat." (Dreyfus 1991, s. 184).
} 
vysvětlit genezi postoje nezaujaté kontemplace $\mathrm{z}$ onoho původnějšího, zainteresovaného porozumění. H. Dreyfus i M. Okrent se tento zrod teorie na základě praxe snaží postihnout rozvinutím Heideggerem poněkud stroze načrtnutých odkazů na praktickou motivaci ke změně postoje, která se ohlašuje $\mathrm{v}$ případech, kdy se prostředky naší činnosti stávají nápadnými, naléhavými či neodbytnými. Při zatloukání hřebíku kladivem nepotřebuji explicitní představu kladiva $\mathrm{v}$ jeho vlastnostech; o kladivo jako předmět se začínám zajímat teprve tehdy, ukáže-li se nápadné v některých svých aspektech (naprríklad jako kluzké), naléhavé (například tam, kde není po ruce) či neodbytné (naprríklad dožadující se opravy). Zejména Dreyfus zdůrazňuje postupnou, třístupňovou strukturu těchto narušení, jež mají v posledku vydat počet o genezi nezaujatého, teoretického postoje: ${ }^{9}$ a) při pouhém narušení hladké činnosti, do níž jsme pohrouženi, se prostředek stává čistě nápadným, ale rychlé postř̌ehnutí některé z jeho vlastností nám umožní rychlé zjednání nápravy a další uvedení věcí do provozu; b) dočasná porucha či náhlá absence prríručního jsoucna nás vytrhává z pohroužení a vede ke zvažování, v jehož rámci vznikají i skutečné představy ohledně předmětnosti prostředků, které si naléhavě žádají řešení; c) avšak teprve trvalé selhání, související s neodbytností, vede od praktického zvažování k teoretickému zájmu o předměty. Důvodem, proč prostředek vyvstává jako předmět a leží před námi ve svých nápadných vlastnostech, je jeho náhlá dysfunkce, nebo jiný zájem o to, co si s ním počít. Struktura příručních jsoucen se stane zjevnou a výslovnou teprve tam, kde člověk vystoupil z důvěrně známé souvislosti, v jejímž důsledku se jejich svébytnost drží v pozadí.

Ve všech těchto stupních je přitom zdůrazněno přerušení probíhajícího zvládání světa prostředků jako nutná podmínka k zaujetí teoretického postoje, nebot' právě v té míře, v níž jsoucna přicházejí o svou př́ručnost, se zároveň ohlašují ve svých vlastnostech a ve své výskytovosti. Je však pouhým odstupem od manipulace dosaženo poznání, potažmo vědeckého postoje? Heidegger na některých místech naznačuje, že poznání věcí v jejich aspektech je př́imým důsledkem zdržení se veškerého používání:

„Toto pohlížení znamená vždycky zaměřit se určitým způsobem na..., vzít si to, co se vyskytuje, na mušku. [...] V takovém ,zdržování se u - které je zdržením se každé manipulace a používání - uskutečňuje se pojímání toho, co se vyskytuje. Toto pojímání probíhá tím způsobem, že oslovujeme a vyslovujeme něco jako něco.“10

Výpověd” „kladivo je těžké“, v níž vyslovujeme kladivo jako něco určitého, se přitom sama vyznačuje jistou stupňovitou genezí, jejíž kořeny vězí v praxi a jejím přerušení: zaprvé spočívá na původnějším odložení kladiva $\mathrm{v}$ jeho nevhodnosti, za druhé může být toto praktické odložení osvojeno konstatováním jednoho $\mathrm{z}$ aspektů tohoto kladiva $\mathrm{v}$ jeho čiré výskytovosti, s odhlédnutím od jeho účelu a zasazení do kontextu dílny. „Vědění-že“ tak má být vysvětleno v termínech ,vědění-jak“ a získání objektivních, pojmově explicitních obsahů

\footnotetext{
${ }^{9}$ Dreyfus (1991, s. 69-83).

${ }^{10}$ Heidegger (1996, s. 81).
} 
má být vyloženo v termínech toho, co je implicitní v nepojmových úkonech praxe. ${ }^{11}$ Poznání věcí v jejich vlastnostech by pak skutečně bylo pouze derivativním modem obstarávání, ve shodě s tezí o primátu praxe tak, jak ji vymezil Blattner.

Proti této interpretaci je však nutno namítnout, že zdržení se veškeré manipulace je dost možná nutnou, nikoli však dostatečnou podmínkou pro zrod teoretického pojímání jsoucna v jeho čiré výskytovosti. „Holá fakta“ jednoduše nevznikají pouze tím, že odhlédneme od kontextu našich zájmů a praktických poukazů. Sám Heidegger upozorňuje, že teoretický postoj nemůže být redukován na „čisté pohlîžení“ či „strnulé zírání“.

„Je nasnadě charakterizovat proměnu z „praktického“ zacházení a používání příručních prostředků na „teoretické“ bádání takto: čisté pohlížení na jsoucno vzniká tím, že se obstarávání zdrží jakéhokoli zacházení. Pro „vznik“ teoretického postoje by pak bylo rozhodující zmizení praxe. Právě vyjdeme-li od toho, že primární a převládající způsob bytí faktického pobytu je „,praktické“ obstarávání, bude ,teorie“ za svou ontologickou možnost vděčit chybění praxe, to znamená určité privaci. Avšak vyřazení určitého specifického zacházení z obstarávací činnosti nezanechá po sobě jednoduše ohled, který je vedl, jako nějaký zbytek. Obstarávání se v takovém prrípadě naopak přesune výhradně do jistého ,už jen hledění kolem sebe‘. Tím však ještě nikterak není dosaženo „teoretického“ postoje vědy. “12

Jak tedy vysvětlit „vznik“ teoretického postoje ke „světu“ na základě původnějšího, praktického obstarávání jsoucna? Nejedná se pouze o poruchou či jiným nedostatkem motivovaný odstup od dalšího manipulování, nýbrž o celkovou změnu porozumění, v němž místo zvažování příručního jsoucna v praktickém ohledu pojímáme toto jsoucno jako výskytové. Proměna praktického obstarávání v teoretické odkrývání je pak proměnou netematického rozumění jsoucnu v jeho příručnosti v tematickou výpověd', která zpř́tomňuje jsoucno v jeho čiré výskytovosti ,zde a nyní“. Má-li se nitrosvětské jsoucno ukázat v souvislosti prričin a účinků, je třeba rozvrhnout bytí předmětů jinak, než tomu bylo v praktickém ohledu vedeném účelem, jehož má být teprve dosaženo. Tato zpřítomňující a objektivizující tematizace přitom nevede knaprostému vytržení nitrosvětského jsoucna z jakéhokoli kontextu, ale předpokládá nový typ re-kontextualizace, kterou Heidegger charakterizuje v souvislosti se vznikem novověké prrírodovědy jako „matematický rozvrh věcnosti“:

„Tento rozvrh předchůdně odkrývá něco stále se vyskytujícího (materii) a otevírá horizont pro směrodatný zřetel k jeho kvantitativně určitelným konstitutivním momentům (pohybu, síle, poloze a času). Teprve „ve světle“ takto rozvržené přírody lze najít něco takového jako „faktum“ a zasadit je do vědeckého pokusu tímto rozvrhem regulativně vymezeného. „Založení“ „vědy o faktech“ bylo

\footnotetext{
${ }^{11}$ Srov. Brandom (2002, s. 77).

${ }^{12}$ Heidegger (1996, s. 357-358).
} 
možné jen proto, že badatelé pochopili: zásadně neexistují žádná ,pouhá fakta“." "13

Z uvedené citace je zřejmé, že proměna obstarávajícího zacházení v nový způsob porozumění jsoucnům v jejich určitelných vlastnostech předpokládá specifický druh úkonů, prováděných vědou od doby Galileiho požadavku na geometrické uchopení prrírodních jevů. V porovnání s Husserlovými analýzami matematické idealizace přírody se Heideggerův stručný náčrt „matematického rozvrhu věcnosti“ může zdát jako př́liš povšechný. Pro konstituci objektů př́rodních věd je přece rozhodující další široká škála metodických, idealizujících a formalizujících operací, směřujících $\mathrm{k}$ zachycení některých rysů přírodních jsoucen jako platných pro každou racionální bytost. Proto je třeba vzít v úvahu i takové principy, jako je vysvětlení prrírodních jevů pomocí čisté kauzality, dále postup měření umožňující dospět k objektivitě jako té dimenzi světa, která je identická pro každého badatele, a konečně i myšlenka nepř́mé matematizace, která předpokládá, že pro jednotlivé kvalitativní danosti naší zkušenosti (jako je např. barva) nalezneme ekvivalent v přísně matematické oblasti časoprostorových forem (jako je napřr. vlnová délka). Tato námitka je oprávněná do té míry, v níž Husserlovy podrobnější analýzy lépe charakterizují onu svébytnou praxi, která umožnila úspěch a účinnost novověké matematické přírodovědy. $\mathrm{Z}$ heideggerovských pozic by bylo možno odvětit, že všechny výše uvedené výkony předpokládají jako svou podmínku ono zpředmětňující pohlížení na přírodu jako na celkovou souvislost změn poloh materiálních těles v čase, který je převeden na lineární sled jednotlivých „ted““. Přesto mám za to, že Husserlův rozbor úkonů spjatých s novověkou geometrizací prírody, byt' jej lze považovat za komplementární vzhledem k Heideggerově „matematickému rozvrhu věcnosti“, ukazuje s větší konkrecí, proč pro genezi teoretického postoje není rozhodující zmizení praxe, ale naopak svébytný druh formalizujících operací, jež proměňují původní životní vztahy v přesně uchopitelná idealia.

Tato úvaha o teorii jako svébytném druhu činnosti nás tak vede $\mathrm{k}$ upřesnění a částečnému přehodnocení onoho primátu praxe, který je zdůrazňován pragmatickými interprety Heideggerova díla: spíše než o převrácení hierarchického poměru teorie a praxe oproti tradici jde spíše o zpochybnění zásadního rozdílu mezi oběma postoji. Stejně jako praxe není a-teoretická $\mathrm{v}$ tom smyslu, že by jí chyběl vlastní ohled, stejně tak teorie není prostá vlastních úkonů, které z ní činí praxi sui generis, disponující vlastními dovednostmi. Smysl Heideggerovy revize tradiční dichotomie teorie a praxe by tak byl blíže Rortyho snaze o prosazení „,pragmatické koncepce poznání, které eliminuje řecké rozlišení mezi kontemplací a jednáním, mezi reprezentováním světa a jeho zvládáním. “14 Heideggerův důraz na praktické vyrovnávání se se světem jako původní vrstvou odhalování jeho významů přitom Rorty uvádí do souvislosti s Deweyho kritikou divácké teorie poznání. Tento termín zavedl Dewey pro označení karteziánsko-lockovské koncepce vědomí jako reprezentace vnějšího světa, podle níž se pravdivé poznání zakládá na speciálních druzích mentálních představ věrně

\footnotetext{
${ }^{13}$ Heidegger (1996, s. 395).

${ }^{14}$ Rorty (2012, s. 20).
} 
zobrazujících transcendentní skutečnost. Zejména Lockova metafora mysli jako temné komory pak vede k představě, že rozumět znamená pojmout vnější zkušenost na základě vnitřních reprezentací, které ji v menší či větší míře adekvátně zobrazují:

„vnější a vnitřní smyslové vnímání jsou jedinými průchody, [...] jimiž se poznání dostává do rozumu. Jen ty samotné [...] jsou okny, jimiž se přivádí světlo do oné temné komory [dark room]. Zdá se mi totiž, že chápání [understanding] se př́lišs neliší od komůrky, zcela vůči světlu uzavřené, ponechávající volné jen malé štěrbinky, aby se umožnilo vpuštění zpodobenin viditelných věcí, čili idejí věcí zvnějšku. Kdyby obrazy, přicházející do takové temnice, v ní pouze zůstaly uspořádaně uloženy, aby mohly být v prrípadě potřeby vyhledány, velmi by se to podobalo chápání člověka, a to vzhledem ke všem zrakovým objektům a jejich ideám. “ 15

Důraz na praktickou angažovanost našeho bytí u věcí, která disponuje vlastním stylem rozumění, jde v tomto ohledu ruku v ruce s kritikou zapouzdřené mysli či „,vnitřní sféry“, na jejíž půdě by pak měl být vykázán vznik objektivity a vnějšího světa s jeho nárokem na platnost. Heideggerův důraz na zjednávající postoj ke světu tak vede nejen ke kritice novověké teorie poznání, vycházející ze studia vědomí v reflexivním postoji, ale i k radikálnímu zpochybnění Husserlovy teze o primátu představy, spočívající v prohlášení objektivizujících, „kladoucích“ aktů vědomí za něco, co nutně předchází veškerým aktům jednání, hodnocení a emocionálním hnutím. Husserlova polemika s Brentanovým psychologismem samozřjmě zpochybňuje pojetí psychična, charakterizovaného intencionální inexistencí objektu ve vědomí. Intencionalita je Husserlovi dynamikou, která v jistém smyslu vytváří vztah k předmětu (jakožto syntéze rozmanitosti). Intencionalita také není vlastností vědomí, ale způsobem, jímž jsme ex-centricky vždy už u věcí, takže Heideggerovu kritiku zapouzdřené mysli nelze vztáhnout na Husserla samotného, jehož intencionální analýzy taktéž směřují k opuštění koncepce mysli jako substance (natož pak temné komory), v níž by se „nacházely“ představy. Navzdory těmto výdobytkům však u Husserla přetrvávají některé zbytky kartesianismu, patrné zejména $\mathrm{v}$ jeho důrazu na zakládající úlohu, která v našem intencionálním vztahování se ke světu náleží objektivizujícím aktům.

Tak je z V. Logického zkoumání zřejmé, že i tam, kde Husserl uznává praktickou i emocionální intencionalitu coby svébytné modality intencionálního zaměření, charakterizuje afektivní a volní prožitky jako založené na představě. ${ }^{16}$ A právě z perspektivy Heideggerovy reflexe o praktické dimenzi našeho původního potýkání s věcmi se lze ptát, zda primát, který Husserl přiděluje objektivujícím aktům, není jen předsudkem motivovaným snahou o založení logiky na pevných a průzračných základech. Byt' tedy Husserl neopomíjí vzájemnou provázanost volních a afektivních aktů a považuje poznání samo za něco motivovaného naším praktickým zájmem o svět, z pragmatického hlediska mu lze vyčíst, že v těchto komplexních prožitcích neprávem postuluje jisté ,jádro smyslu“, které by mělo svůj objektivizující

\footnotetext{
${ }^{15}$ Locke (1984, s. 115).

${ }^{16}$ Srov. Husserl (2010, s. 396-398).
} 
charakter a které by stálo jako původnější základ, nesoucí afektivní a praktické vrstvy vědomí. Právě v protikladu k těmto tezím pak získává nový význam důraz na praxi jako původní způsob, v němž se lidská existence vyrovnává se světem. Jestliže se člověk setkává s věcmi jako s koreláty svých praktických možností a úkolů, pak také padá ona primordialita připisovaná představě a názoru coby základu všech vyšších, fundovaných aktů vědomí.

Ze všech těchto důvodů nelze model poznání, založený na tematickém uchopení jisté předmětnosti, považovat za zcela adekvátní formu, jak vydat počet o našem setkání s věcmi. Hledáme-li tedy význam primátu praxe, který by byl nejblíže Heideggerově vlastní intenci, pak bychom jej mohli najít $\mathrm{v}$ onom vodítku, které nám poskytuje naše každodenní rozumění věcem jejich zvládnutím: „Na rovině ontické užíváme výrazu „něčemu rozumět“ ve významu „,být s to nějakou věc zvládnout“, „,něco zmoci“, „,něco moci““،17 Světský a každodenní smysl německého slova Verstehen s jeho praktickými konotacemi tak skýtá příležitost, jak se prohloubením významů $\mathrm{v}$ něm obsažených propracovat k existenciálnímu pojmu rozumění. Toto vodítko - tento model zvládání - pak slouží jako protilék na onu utkvělou prèedstavu, která se prosadila v souvislosti s novověkou epistemologickou revolucí a která chápe vztah člověka ke světu modelem poznávajícího subjektu, konfrontovaného s celkem věcí určených k poznání. Vysvětlit rozumění $\mathrm{v}$ termínech implicitních dovedností naopak umožňuje pochopit jeho hlubší základ, jímž je má existence coby uskutečňování možností. Je totiž zjevné, že možnosti, jimiž jsem, nerealizuji ve svém vědomí, ale jedině a pouze svým praktickým angažováním ve světě, který vždy už sdílím s druhými. Touto cestou, která rozumění váže na naši praxi, pak lze odstranit i převahu vizuálních metafor, které přetrvávají jako pozůstatek reprezentačního pojetí rozumění: nechápeme věci vnitřním zrakem a zaměření intencionálního paprsku na předmětnost není primárním způsobem, jímž se vztahujeme $\mathrm{k}$ věcem. Ve své původní podobě znamená rozumění tolik co obstarání věcí, jejich zvládání, přetváření, užívání či konec konců také jejich ponechání tím, čím jsou.

Primát praxe tak získává poněkud jiný smysl než je ten, o kterém byla řeč v úvodních odstavcích této kapitoly, kde byla praxi přisuzována priorita jednak ve smyslu chronologickém, jednak ve smyslu fundačním. Zejména H. Dreyfus se nezdráhá vykládat primát praxe mimo jiné v tom nejbanálnějším, chronologickém smyslu: lidské bytosti „,zprvu a většinou“ rozumí věcem na základě jejich pohrouženého obstarávání, k němuž nepotřebují reprezentace. Chronologická priorita je zde myšlena jak psychogeneticky, s důrazem na „Zuerst“ (nejprve věci zvládáme a teprve potom si o nich vytváŕíme představy), tak statisticky, s důrazem na „zumeist“ a na každodenní převahu pohrouženého obstarávání vůči tematickému zvažování. Velkou část našich životů - při práci, cestování, mluvení, jedení, řízení atd. - totiž podle Dreyfuse trávíme ve stavu takového zvládání, k němuž si nepotřebujeme utvářet představy cílů a prostředků $\mathrm{k}$ jejich dosažení, a pouze tam, kde toto zvládání selhává, jsme motivováni k tematickému zvažování a utváření představ. ${ }^{18}$ Tento chronologický smysl primátu praxe pak u většiny pragmatických interpretů získává význam

\footnotetext{
${ }^{17}$ Heidegger (1996, s. 170).

${ }^{18}$ Dreyfus (1993, s. 27).
} 
fundační, nebot' co je první, zdá se být i základní. V této perspektivě se zpředmětňující postoj ke světu a poznání věcí v jejich vlastnostech jeví jako odvozený modus netematického zacházení s věcmi. ${ }^{19}$ Teze o primátu praxe však může také znamenat, jak jsem se snažil ukázat v poslední části této kapitoly, že pohroužené obstarávání a praktické zvládání světa slouží jako model pro lepší pochopení rozumění jako jednoho ze způsobů, jímž člověk prodlévá ve světě.

Proti oběma prvním výkladům lze navíc namítnout, že nerespektují výhrady, v nichž se Heidegger snažil předejít interpretaci své analytiky každodenního obstarávání v termínech „primátu praxe“. „Primát praxe“ vyložený v termínech toho, co člověk činí ve světě ,zprvu a většinou“, se zdá být diskvalifikován upřesněním, jímž Heidegger ve své knize o Kantovi zrazuje vlastní vykladače od lpění na kladivech, zatloukání a jiných habituálních praktikách našeho prodlévání ve světě:

„existenciální analytika každodennosti nechce popisovat, jak zacházíme s nožem a vidličkou. Má ukázat, že a jak veškeré zacházení se jsoucím, při kterém to právě vypadá tak, jako kdyby se vyskytovalo jen jsoucí, má už za základ transcendenci bytí-tu - bytí-ve-světě. “20

Druhý výklad praxe jako fundujícího modu teorie pak stojí v ostrém protikladu vůči Heideggerově explicitnímu odmítnutí primátu praxe před teorií v $\$ 41$ Bytí a času:

„Starost jako původní strukturální celek je existenciálně-apriorně „,před“ každým, tzn. vždy již v každém faktickém ,chování“ a „situaci“ pobytu. Proto tento fenomén v žádném prrípadě nevyjadřuje nějakou přednost „praktického“ chování před teoretickým. Pouhé nazírající určování výskytového jsoucna má charakter starosti neméně než ,politická akce“ nebo poklidný odpočinek. „Teorie“" a ,praxe“ jsou bytostné možnosti jsoucna, jehož bytí je nutno určit jako starost.“21

Jak patrno, Heideggerovi primárně nejde o prvořadost praktického chování a odvozenost teoretického postoje. Odkazem na ukotvenost teorie i praxe v bytí, které musí samo sebe převzít jako úkol, chce spíše ukázat, že ani praktickou aktivitu, ani kontemplativní poznávání nelze pochopit jako vztah mezi sebe-zajištěnou subjektivitou (s jejími intencionálními obsahy) a nezávislými objekty, jejichž souhrn tvoří svět. Toto zpochybnění těsně souvisí s přehodnocením celé dosavadní ontologie, tj. s revizí způsobu, jímž bylo v západní filosofické tradici pojímáno bytí věcí i nás samých. Mưžeme tak navzdory výše uvedené citaci, která výslovně diskvalifikuje obhajobu „přednosti teoretického chování před praktickým“, nadále hovořit v souvislosti s Heideggerovou analytikou pobytu o jakémkoli „,primátu praxe“? V následujících řádcích se pokusím prokázat, že interpretace našeho „moci-

\footnotetext{
${ }^{19}$ Srov. Haugeland (2013, s. 195): „teoretické rozumění je téměř vždy odvozené (byt' i skrze několik zprostředkujících stupňů) z předchozích před-teoretických způsobů rozumění, jež jsou samy založeny na praktických dovednostech či nesnázích."

${ }^{20}$ Heidegger (2004, s. 204).

${ }^{21}$ Heidegger (1996, s. 222).
} 
být“ v termínech široce chápané praxe není zcestná, ale umožňuje nové převzetí Heideggerova ontologického rozvrhu.

\section{Primát praxe jako ontologická teze}

Jak vyplývá z citovaného $\S 41$, Heidegger přiznává absolutní primát nikoli praktickému chování, nýbrž „starosti“, která je klíčem pro porozumění všem dalším vztahům pobytu k sobě samému, k nitrosvětskému jsoucnu i k druhým já. Pouze na základě starosti, která je chápána (existenciálně-ontologicky) jako „bytostně nedílná celost“ pobytu, můžeme vysvětlit dílčí rozdíly mezi jednotlivými modalitami bytí pobytu: sám rozdíl „teorie“ a „praxe“ tak musí být vyložen jako výsledek diferenciace obstarávajícího chování a vztahování ke světu, a nikoli jako původní a dále neredukovatelná diference. Jak je dále z Heideggerovy výhrady zřejmé, důraz kladený na praktické zacházení jako prvotní způsob setkání s věcmi nemá vést k převrácení tradiční hierarchie kladoucí poznání za podmínku jednání, ale k přehodnocení ontologického rámce, $v$ němž byla otázka ohledně přednosti teorie či praxe v moderní filosofii kladena.

Jaké jsou předpoklady tradičního rozlišení mezi teoretickým a praktickým postojem? Běžně máme za to, že v teoretickém uvažování stojí v popředí otázka toho, čemu máme věřit a co lze spolehlivě poznat. Naopak v praktickém uvažování se náš zájem upíná k tomu, co zamýšlíme vykonat a jakých prostředků $\mathrm{k}$ tomu použít. Zatímco $\mathrm{v}$ prvním případě je naším cílem zjistit, jak se to se světem má, v druhém jde o to, jak svět změnit. ${ }^{22}$ Ačkoli se na první pohled jedná o dva rozdílné typy zaměření, odpovídající dualitě přesvědčení a tužeb v našem vědomí, Heideggerův obrat směřuje právě ke zpochybnění takto ostrého rozlišení dvou typů postojů ke světu a ukazuje jejich společný původ. Mezi diferenciace, jež nelze chápat jako primární, ale jako vycházející z celkového charakteru našeho bytí-ve-světě, proto Heidegger v 441 řadí nejen rozdíl praktického a teoretického chování, ale také zvláštní akty běžně připisované vědomí, jako jsou chtění, přání, pudy, či sklony. ${ }^{23}$

Jestliže tedy Heidegger zdůrazňuje, že ani praktická aktivita, ani nezaujaté poznání není primární, pak je to proto, že pouhé převrácení priorit ponechává nedotčen základní rozvrh novověké epistemologie, v němž se poznávající subjekt vztahuje prostřednictvím svých cogitationes k objektům mimo svou mysl. Za účelem zrušení tohoto epistemologického schématu se však Heidegger podle mého názoru nežríká možnosti přisoudit praxi jistou prvořadou roli, která zároveň vede k samotné revizi tohoto pojmu. Oproti ontologické nevyjasněnosti pojmu praxe v prostém prohlášení o ,primátu praxe vůči teorii“ je proto třeba postavit problém praxe na ontologickou rovinu a vyložit jej ze samotného pojmu existence. Právě k tomu směřuje Heideggerovo zjištění, že starost o vlastní bytí je současně zdrojem teoretického vědění i svobodného jednání.

\footnotetext{
${ }^{22}$ Srov. např. samozřejmost, s níž Searle rozlišuje mezi přesvědčením a přaním na základě jejich odlišného způsobu zaměření: zatímco $\mathrm{v}$ případě přání či tužeb jde o to změnit svět podle našich požadavků, u př̌esvědčení jde o přizpůsobení představ stavům světa. (Searle 1983, s. 7).

${ }^{23}$ Heidegger (1996, s. 222).
} 
Začněme otázkou samotného bytí pobytu ve vztahu k praxi. Heidegger na mnoha místech Bytí a času zdůrazňuje, že na úrovni každodenního porozumění rozumíme sami sobě prvotně z toho, co konáme. Každý z nás je „zprvu a většinou“ tím, oč usiluje, a sám sobě rozumí na základě způsobu, jímž je činný ve světě: „Pobyt nachází sebe sama prvotně v tom, co dělá, potřebuje, očekává, čemu brání - v prvotně obstarávaném příručním jsoucnu našeho okolí،“24 $\mathrm{S}$ trochou nadsázky tak lze říci, že švec nachází sám sebe v botě, kterou zašívá, kovář v podkově, kterou kuje, a byrokrat ve formulářích, které mu strukturují svět. Samozřejmě to neznamená, že by snad švec sám byl zašívanou botou, tato zkratka spíše naznačuje, že rozumí sám sobě ve svém bytí na základě věcí, s nimiž má co do činění. Cesta $\mathrm{k}$ sobě je tak cestou k věcem: pouze na základě své světské praxe může já prrijít k sobě sama. Mezi světem a mnou tak není trhlina, nebot' rozumění světu a rozumění sobě jsou dvě strany téže mince. $Z$ toho plyne, že právě svou praxí se Dasein odhaluje původněji než teoretickou reflexí. Hegelovým slovníkem bychom mohli říci, že Dasein se musí zvnějšnit, zpředmětnit svou činností, nebot' toliko v ní může stvrdit svou vlastní pravdivost. Heidegger se však termínům jako je zvnějšnění vyhýbá, nebot' tento slovník již předpokládá rozdělení vnitřku a vnějšku, kterého se chce v Bytí a čase zbavit poukazem na vždy-již-vnější charakter pobytu.

Lze však z toho spolu s Dreyfusem vyvodit i to, že Dasein je praxí? Lze založit existenciální výklad pobytu na jeho zacházení s nástroji, jak k tomu dochází v interpretaci Marka Okrenta? ${ }^{25}$ Primát praxe by pak znamenal nejen to, že zprvu a většinou své bytí odhaluji v praktické konfrontaci se světem, ale získal by fundační význam teze, podle níž je veškerá srozumitelnost mého bytí-ve-světě srozumitelná na základě účelových aktivit, které v něm vykonávám. Právě tuto pragmatickou perspektivu na vlastní bytí klade Dreyfus jako centrální, když Heideggerovo pojetí pobytu klade do protikladu k chápání člověka jako subjektu:

„V protikladu k výkladu člověka jako subjektu nám Heidegger připomíná, že jakožto bytí-ve-světě se musí Dasein vztahovat k sobě samému a musí být vyložen na základě „toho, co dělá, potřebuje, očekává, čemu brání.“ [SZ, 119]. [...] Jinými, drsnějšími slovy: „,Člověk jec to, čím se zabývá.“ [SZ, 239]“. ${ }^{26}$

Je-li naším cílem mj. posoudit oprávněnost pragmatického výkladu Heideggera vzhledem k výchozím textům, je v tomto ohledu nanejvýš výmluvné, že Dreyfus Heideggerovu větu zdánlivě ztotožňující „,člověka“, jeho „bytí“ a jeho praktickou pohrouženost vytrhává nejen

\footnotetext{
${ }^{24}$ Tamtéž, s. 145.

25 „Nakolik má podle Heideggera pobyt praktické porozumění prostředkům, natolik má také existenciální [zdůraznil O. Š.] porozumění sobě samému jakožto implicitnímu účelu své činnosti s nástroji. Jak říká Heidegger, ,rozumíme sobě samým na základě činností, které provádíme a věcí, které obstaráváme“. Rozvrhovat sebe sama jako možnost znamená porozumět sobě samému jako určitému „kvůli něčemu“, a dosáhnout takového porozumění pro člověka znamená disponovat praktickým porozuměním prostředkům.“ (Okrent 1988, s. 38). Pojem pobyt pak v Okrentově interpretaci takřka splývá s pojmem homo faber: „Podle Heideggera jednám lidským způsobem do té míry, v níž používám nástroje jako nástroje (...).“(Okrent 2010, s. 299).

${ }^{26}$ Dreyfus (1991, s. 147).
} 
z uvozovek, jimiž Heidegger naznačuje svůj odstup od podaného vymezení, ale především z kontextu $\$ 47$, který jí dává téměř opačný smysl než je ten, k němuž Dreyfusova interpretace směřuje. Zatímco „každodenní pobyt“ si podle Heideggera skutečně „zprvu a většinou rozumí z toho, co je zvyklý obstarávat““27, teprve vytržení z tohoto každodenního obstarávání (zejména v důsledku explicitní konfrontace s vlastní konečností) odhaluje pobyt jinak, totiž v jeho nezastupitelnosti a v jeho možnosti být celý. Daná pasáž tak jasně ukazuje, že v praktickém ohledu je rozumění vlastnímu bytí překryto pseudo-jasností našich sociálních rolí: Heidegger zde odkazuje k pouze zdánlivé zastupitelnosti jednoho pobytu druhým, proti níž staví nemožnost zastoupit druhého v jeho umírání, tj. v jeho nejvlastnější a nepředstižné možnosti. Teprve v úzkosti se pobytu ukazují nejvlastnější možnosti jeho bytí samy o sobě, „nepřekryty nitrosvětským jsoucnem, k němuž se pobyt zprvu a většinou upíná.“28 Zde se srozumitelnost vlastního bytí i světa, získaná praktickým obstaráváním, už nejeví jako něco základního, z čeho by měla být odvozena veškerá další jasnost ohledně lidské situace ve světě. Oproti falešné jasnosti sebe-porozumění z toho, čím se zabývám, zde vystupuje do popředí nový typ jasnosti mé existence jako „vždy mé vlastní“, nezastupitelné.

I zde se znovu ukazuje celková problematičnost teze o primátu praxe, kterou jsme spolu s Blattnerem definovali jako odvozenost srozumitelnosti lidského života z jeho praktického vyrovnávání se se světem. Z perspektivy existenciálního sebe-uvědomění se tato původní srozumitelnost našeho bytí ani zdaleka nejeví jako základní, nýbrž jako falešná. Její nedostatečnost se projevuje zejména $\mathrm{v}$ tom, že při zacházení $\mathrm{s}$ věcmi a sebeidentifikaci se společenskými úkony a rolemi přicházím o možnost odhalit své bytí jako celek: každá praktická činnost, každá společenská role má svou mez, nikdy nejsem jenom ševcem, otcem nebo Čechem, ale všemi těmito rolemi zároveň, přičemž mé bytí-zde se nevyčerpává úhrnem těchto úloh. Proto také Heidegger v $\$ 45$, na počátku druhého oddílu Bytí a čas, připomíná, že „dosavadní existenciální analýza si nemůže činit nárok na pưvodnost. V před-se-vzetí bylo vždy jen neautentické bytí pobytu, a to jako necelé. “29

Přesto má důraz na primát praxe opět jisté částečné opodstatnění, které jsme již načrtli výše: a) brání chápat sebe-porozumění odděleně od zvládání světa; b) zbavuje nás jako interprety předsudku, že Heidegger zavedením termínu pobyt pouze nahradil Husserlův subjekt jako zdroj veškeré smysluplnosti světa; c) a konečně naznačuje odlišnou časovou strukturu pobytu oproti výskytovému jsoucnu. Proti Husserlově tezi, že vědomí je v reflexi na vlastní prožívání dáno sobě sama s apodiktickou evidencí, obhajuje Heidegger pohled na člověka jako na bytost, jež nabývá praktické jasnosti o sobě realizací možností ve světě a ve vztahu k druhým. Naše vlastní bytí nám totiž nikdy není předestřené, jako například bytí tohoto stolu přede mnou, nýbrž je principiálně nehotové, musíme je neustále vykonávat. Získání jasnosti zde proto nemůže mít charakter vyplněného názoru, nebot' každé projasňování zde musí vzít úvahu i vztah $\mathrm{k}$ tomu, co ještě není a co již není. Byt' tedy

\footnotetext{
${ }^{27}$ Heidegger (1996, s. 270).

${ }^{28}$ Tamtéž, s. 220.

${ }^{29}$ Tamtéž, s. 263.
} 
Heidegger odmítá hovořit o přednosti praktického chování před teoretickým, nebot' hodlá obě tyto modality vyložit na základě ontologické analýzy pobytu jako starosti, přesto právě praxe poskytuje (oproti stanovisku poznávajícího subjektu) lepší vodítko pro pochopení způsobu, jímž prodlévám ve světě. Analogicky k praxi totiž starost a nelhostejnost pobytu k vlastnímu bytí znamená, že toto bytí musí být jeho výkonem, že je musí výslovně či nevýslovně převzít. Pobyt se vztahuje k sobě samému nikoli obrácením pohledu do vlastního nitra, nýbrž svým konáním.

Byt' se tedy nadále přidržujeme výkladu pobytu $\mathrm{v}$ termínech praxe, na rozdíl od jednostranně pragmatických interpretací nechceme zamést pod rohožku, že právě v tomto praktickém charakteru našeho sebe-vztahu tkví hlavní nesnáz onoho úkolu, jímž je projasnění povahy našeho bytí. Jestliže si totiž rozumím z možností, do nichž se prakticky rozvrhuji, a jestliže tyto možnosti mají zprvu a většinou podobu plnění úkolů, obstarávání dobrého bydla či zajištování sebe sama ve světě, pak se můj sebe-vztah skrze svět uskutečňuje v podobě zvěcnění, a tedy v podobě zásadního neporozumění bytostnému rázu mé existence. Právě vůči tomuto neporozumění pak může a má být vydobyta nová podoba jasnosti a srozumitelnosti. S touto výhradou lze nadále považovat za nezbytné podržet prvořadý význam praxe, nebot' ani tohoto úkolu překonání průměrné srozumitelnosti se v posledku nelze zhostit jinak než prakticky: nestačí například poukazovat na to, že převládající forma spolubytí vede $\mathrm{k}$ instrumentalizaci lidských vztahů, ale je potřeba dostát tomuto náhledu změnou svého poměru k druhým. Nestačí jen teoreticky konstatovat, že dnešní provoz filosofie nás strhává k takové formě obstarávání výuky, která se vzdaluje filosofické činnosti ve vlastním slova smyslu, ale je nevyhnutelné právě proměnou této neblahé praxe revidovat kritéria toho, co to znamená být filosofem. Také pranýřování akademismu by ze strany malíře bylo pouhým prázdným gestem, jestliže by se mu tvorbou nových forem, byt' v konverzaci s tradicí, nepodařilo alespoň zčásti pozměnit stávající praxi uměleckého ,provozu“. Ve všech těchto případech je tak nová jasnost nevyhnutelně spjata s jistou modifikací dosavadní praxe.

Z Heideggerovy teze, podle níž si pobyt rozumí ze světa, tj. je ve svém výkladu vždy již ovlivněn porozuměním světu, mimo jiné plyne, že překonání subjektivismu ve fenomenologii nelze dosáhnout jednostranně, totiž přehodnocením bytí samotného pobytu, ale jedině se současnou revizí onoho metafyzického pojetí věcí coby souhrnu vyskytujících se objektů, které nás drží v zajetí jak při výkladu světa, tak ve vlastním sebe(ne)porozumění. Ontologické prošetření praxe a její role ve vzájemně provázaném odhalování bytí pobytu i zjevování světa by tedy nebylo úplné, jestliže by nezahrnulo také problematiku bytí samotných věcí, tak jak se s nimi zprvu a většinou setkáváme.

V poslední části této stati tak chceme nově interpretovat úlohu, kterou pro zjevování věcí hraje naše praktická pohrouženost do světa. Za tímto účelem je třeba nově interpretovat heslo „k věcem samým!“ tak, abychom věcmi nechápali ani vnější předměty naivního objektivismu, ani věci coby koreláty názoru Husserlova transcendentálního idealismu, ale spíše věci jako pragmata, jako věci, s nimiž máme co do činění. Heideggerova analýza začíná 
otázkou po „bytí jsoucna, s nímž se nejbezprostředněji setkáváme“30 a dochází k závěru, že toto bytí je třeba pojmout jako prríručnost, resp. jako dostatečnost, vhodnost „,k tomu a tomu“. Jak známo, pro věci odhalující se pobytu v jejich vhodnosti k danému úkolu či rozvrhu volí Heidegger termín „,p̌ríruční jsoucno“, aby tak zdůraznil, že s věcmi se prvotně setkáváme jako s něčím, co je při ruce vzhledem k tomu, co hodlám vykonat. Ve své původní bytostné skladbě se mi tak věci nejeví jako koreláty názoru či nezaujatého vnímání, ale jako organické součásti mého praktického jednání. Ontologický výklad našeho ontického, každodenního způsobu setkávání s věcmi tak směřuje k novému významu primátu praxe, jímž je ontologická priorita příručního jsoucna vůči jsoucnu, které je pouze přítomné jako něco vyskytujícího se a nadaného vlastnostmi:

„Teprve po proniknutí jsoucnem, které je v obstarávání po ruce, uvolňuje poznání pouhé jsoucno výskytové. Příručnost je ontologicko-kategoriální určení jsoucna, jak je „o sobeّ“.“ 31

Tezi o ontologické prioritě př́ručnosti vůči výskytovosti je nutno chápat $\mathrm{v}$ kontextu Heideggerovy destrukce substancialistické metafyziky, která naopak předpokládá, že určité jsoucno může prakticky sloužit člověku či získávat jisté normativní rysy teprve na základě svého výskytu. Jak ukazuje Heidegger, tato tradice opomíjí fundamentální podmínky možnosti zjevování toho, co je ve své přítomnosti již prostě jen zde. Důraz na primát praktického zacházení s nitrosvětským jsoucnem přitom ukazuje, že vlastní bytí věci jsme vždy již minuli, pokud jsme je charakterizovali jako výskyt nějaké rei.

Co konkrétně jsme redukcí věcí na vyskytující se res minuli či zkomolili? Součástí Heideggerovy kritiky substancialistické tradice je zejména důraz na nemožnost chápat věc jako samostatně stojící, tj. izolovaně od jejích vztahů k okolí. Na rozdíl od předmětu, stojícího před zrakem subjektu v izolované podobě, jako jednotlivá a do sebe uzavřená skutečnost, se pragmata zjevují ve svých poukazech na celek a jsou vzájemně spjata vždy již předem artikulovanou strukturou vzájemného odkazování. Jinými slovy, věci by nemohly být tím, čím jsou, nebýt oné prakticky členěné souvislosti, do níž zapadají. Př́kladem takovéto souvislosti toho, jak se k sobě věci mají, může být zrovna tak Heideggerova truhlářská dílna jako moje pracovna: místo, kde pracuji, tvoří psací stůl, lampa, knihovna, počítač, modem s připojením $\mathrm{k}$ internetu, ale toto místo není totožné se seznamem či součtem věcí, které se v něm vyskytují; mnohem lépe je lze charakterizovat vzájemnou provázaností všech těchto prostředků, kterou Heidegger nazývá „,celkovou souvislostí poukazů“ [Bewandtnisganzheit]. Vědět, jak něco používat, tedy spočívá v praktickém zvládnutí této souvislosti, byt' ona sama nestojí v průběhu dané činnosti v centru pozornosti. Prapůvodní podobou vztahu k věcem tak není přímé zaměření na předměty, ani na objektivní vztahy mezi nimi, nýbrž praktické uchopení nějaké věci coby prostředku v rámci jistého celku dostatečnosti.

S tím souvisí další charakterizace věci jako toho, k čemu zprvu nezaujímám

\footnotetext{
${ }^{30}$ Tamtéž, s. 87.

${ }^{31}$ Tamtéž, s. 92.
} 
objektivizující postoj. Prostředek je tím, čím je, právě tehdy, když od sebe odvádí pozornost; je pro něj ,,charakteristické, že se ve své příručnosti jaksi drží v pozadí, a to právě proto, aby byl ve vlastním smyslu po ruce. “32 Prostředek, například stůl, na kterém píšu tento text, je pro mě zprvu a většinou nepředmětný: nesetkávám se s ním jako s předmětem, jehož primárními vlastnostmi by bylo to, že se vyskytuje na daném místě časoprostoru a že mu náleží ty a ty predikáty. Jak jsme viděli již v první kapitole, tato transparentnost či neviditelnost stolu se promění v něco vystupujícího do popředí teprve tehdy, jestliže se stůl stává „nápadným“, „,naléhavým“ či neodbytným“, např. pokud se při psaní začne kývat a bude třeba jej podložit, došroubovat či nechat opravit: teprve poté se na něm ohlašuje jeho „charakter výskytovosti“, byt' je i tento rys stále potlačován ve prospěch nové použitelnosti, zjednané co nejrychlejší nápravou. Jsoucno ve svých aspektech, v tom, co na něm lze konstatovat jako vlastnosti, se tedy stává zjevným a výslovným teprve poté, co vystoupilo z důvěrně známé souvislosti, která stolu umožňuje být stolem, totiž něčím dostatečně pevným, na čem se dá psát, jíst či na co lze položit popelník.

Vkrádá se však podezření, že věci, o nichž zde Heidegger hovoří, tvoří pouze jistou podmnožinu toho, s čím se ve světě setkáváme. Každé okolí přece nemá charakter pracovny či truhlářské dílny a věci utvářející svět našeho života nelze redukovat pouze na věci používané za ryze praktickými účely! Nesměřuje tak Heideggerův výklad ve svém důsledku $\mathrm{k}$ redukci věcí na význam, které mohou mít pro člověka? V tomto ohledu je pozoruhodné, že Heidegger do své analýzy způsobu, jímž prakticky rozumíme věcem našeho okolí, zahrnuje i jsoucna lidskou rukou nestvořená, ale přesto lidským úsilím zvládnutá a racionalizovaná: i příroda se jeví zprvu ve své příručnosti „k něčemu“ a jako výskyt může být stanovena teprve druhotně, v teoreticky objektivizujícím rozvrhu:

„Les je obora, hora je kamenolom, řeka je vodní síla, vítr je „vítr v plachtách“. Zároveň s odkrytým „světem našeho okolí“ setkáváme se s takto odkrytou „přírodou“. Od jejího způsobu bytí jako jsoucna, které je po ruce, můžeme odhlédnout a odkrýt a určit ji samu výhradně v její čisté výskytovosti.“33

I zde se potvrzuje, že bytí přírodních jsoucen je zprvu odkryto zainteresovanou praxí. Avšak samo pokračování této pasáže, která zdánlivě dává za pravdu ryze pragmatickému výkladu Heideggerovy ontologie, nás nutí revidovat ztotožnění celku jsoucna se souhrnem vzájemně provázaných prostředků, $\mathrm{k}$ němuž pragmatické interpretace směřují. Právě příklad toho, čím může být člověku přírodní jsoucno, totiž ukazuje, že je nelze chápat ani jako výskyt, avšak ani jako pouhý prostředek. Oba tyto způsoby odhalení totiž nevyhnutelně ústí k překrytí jiných, pro člověka stejně tak podstatných způsobů bytí prrírody, jejíž celkový význam tak nelze redukovat ani na prostředek určený $\mathrm{k}$ využití, ani na čirou hmotu v pohybu novověké přírodovědy. Citovaná pasáž tak končí poukazem na možná původnější prodlévání člověka ve světě, v němž je nám příroda rovněž tím,

\footnotetext{
${ }^{32}$ Tamtéž, s. 90.

${ }^{33}$ Heidegger (1996, s. 91).
} 
„,co tká a vlá‘, co nás přepadá, co nás jako krajina uchvacuje. Botanikovy rostliny nejsou květiny na mezi, zeměpisně fixovaný ,pramen“ řeky není ,zřídlo v hlubině‘، ، 34

Stejně tak je nutno podotknout ohledně způsobu, jímž se nám v našem každodenním žití odhaluje bytnost stolu, že se nevyčerpává svým ryze instrumentálním bytím-podložkou pro talîr, počítač či unavené ruce, ale že je zrovna tak stolem, který počmáraly děti, či místem, k němuž zveme přátele ke společnému posezení. Sám Heidegger ostatně tuto širší intersubjektivní dimenzi rozvádí již ve svých přednáškách z letního semestru $1923 .{ }^{35}$ Bylo by proto chybou vykládat praxi čistě v termínech manipulace s prostředky.

Aniž by na tomto omezeném místě bylo možno podat ucelený přehled Heideggerovy vícevrstevnaté analýzy světskosti, je třeba podotknout, že ani pojem světa nelze vykládat čistě v termínech funkčních odkazů, jako nejzazší souvislost všech prostředků. Výše zmíněný příklad truhlářské dílny, v níž na sebe jednotlivé hřebíky, kladiva, kleště a materiály navzájem odkazují, vede Marka Okrenta k závěru, že svět sám je jakousi makro-dílnou, v níž jsou všechny dílčí souvislosti funkčních poukazů zahrnuty coby její podmnožiny:

„Svět je tím nejobecnějším, všezahrnujícím polem funkčních vztahů, díky nimž prakticky rozumíme každé věci, s níž se setkáváme. Svět je, dá-li se to tak říci, funkčním kontextem všech funkčních kontextů, celkem, v němž mají všechny celky prostředků své místo.",36

Je pravda, že takovéto interpretaci dává zdánlivě za pravdu § 16 Bytí a času, v němž je nepoužitelnost určitého prostředku motivací změny postoje, která vede k odhalení toho, do čeho jsme vždy již pohrouženi: v důsledku absence či poruchy př́ručního jsoucna se dostává do zorného pole sama dílna jako to, v čem se naše obstarávání již dříve pohybovalo. Pracovní souvislost dílny a díla je přitom celkem, který dosud nebyl tematizován, byt’ jsme jej měli stále na očích, a o němž Heidegger sám tvrdí, že se v něm „ohlašuje svět.“37 Nejen podle Okrenta, ale též podle Dreyfuse se nám proto fenomén světa odhaluje tak, jako se nám zjevuje sama dílna $\mathrm{v}$ případě chybějícího nářadí. ${ }^{38}$ Jde však o pouhé problesknutí světa, které ještě není jeho odhalením jako fenoménu. Pragmatická interpretace fenoménu světa by pak měla pokračovat úvahou, která bere v potaz strukturální podobnost $\S 16$, v němž se svět našeho okolí (např. dílna) ukazuje teprve tehdy, když prostředky přestávají plnit svou funkci, a $§ 40$, v němž se svět sám ukazuje teprve tehdy, když sám svět našeho okolí ztrácí svou běžnou funkční orientovanost. ${ }^{39}$

\footnotetext{
${ }^{34}$ Tamtéž.

${ }^{35}$ Heidegger (1995, s. 116).

${ }^{36}$ Okrent (1988, s. 42).

${ }^{37}$ Heidegger (1995, s. 96).

${ }^{38}$ Dreyfus (1991, s. 99).

${ }^{39}$ H. Dreyfus tuto cestu naznačuje, ale dostatečně nerozvádí, v kapitole věnované narušení naší běžné praxe, které je význačnou příležitostí pro odhalení fenoménu světa. Srov. Dreyfus (1991, s. 99-100).
} 
Avšak dílna není světem ve zmenšeném měřítku, ani svět není nejzazší celkovou souvislostí manipulovatelného jsoucna, jak odhaluje právě onen pozdější $§ 40$, v němž je náš celkový vztah ke světu do jisté míry převrácen $v$ důsledku úzkosti jakožto význačného způsobu našeho naladění. Oproti Okrentově charakterizaci světa jako nejobecnějšího pole funkčních vztahů zde vysvítá, že svět jako takový se odkrývá teprve ztrátou veškeré významnosti nitrosvětského jsoucna.

„V tom, z čeho je nám úzko, se stává zřejmým: „není to nic a není to nikde“. Neuchopitelnost nitrosvětského ,nic' a ,nikde 'fenomenálně znamená: to, z čeho je nám úzko, je svět jako takový. Naprostý nedostatek významnosti, který se v tomto ,nic‘ a ,nikde‘ ohlašuje, neznamená neprrítomnost světa, nýbrž říká, že nitrosvětské jsoucno samo o sobě je nyní natolik nezávazné, že jediné, co se nám na základě této ztráty významnosti všeho nitrosvětského vnucuje, je už jen svět ve své světskosti. “40

Jak plyne z této pasáže, svět jako takový [Welt] se zjevuje pouze za podmínky, že přestává fungovat ona vzájemná souvislost poukazů, které strukturovaly svět našeho okolí [Umwelt]. Teprve když se svět našeho okolí zhroutí ve své závažnosti, může fenomén světa samého vystoupit do popředí. Svět v silném slova smyslu proto nemůže být chápán ani jako souvislost veškerého manipulovatelného jsoucna, ani jako nejzazší horizont všech praktických a funkčních poukazů, nýbrž jako to, co zůstává ve formě otázky po našem zařazení do veškerenstva vůbec. Na rozdíl od funkční srozumitelnosti dílny je přitom svět charakterizován tísnivou nehostinností a naše postavení v něm se vyznačuje fundamentální nezabydleností, která je v přímém rozporu s důvěrnou obeznámeností našeho každodenního zvládání věcí jako prostředků. I zde se tedy ukazuje podstatná mez oné teze o primátu praxe, která postuluje praktické rozumění jako nejpůvodnější vrstvu, z níž má být odvozen veškerý význam a srozumitelnost lidského života a světa.

$$
* * *
$$

Jestliže mnohé Heideggerovy příklady zejména z prvního oddílu Bytí a času svádějí $\mathrm{k}$ interpretaci jeho díla $\mathrm{v}$ termínech primátu praxe, je nezbytné se nejprve ptát, zda se touto prioritou myslí a) pouze chronologická předchůdnost, v níž ,zprvu a většinou“ žijeme v praktickém obstarávání, b) fundační odvozenost formulování a verifikování teorií, jejichž základem by bylo praktické zvládání světa, či c) radikální revize tradičních ontologických kategorií a nové pojetí bytí člověka, věci i světa. Co se epistemologických otázek týče, snažili jsme se poukázat na zřejmé nedostatky Blattnerova vymezení primátu praxe $\mathrm{v}$ termínech odvoditelnosti veškerého významu lidského života a světa $\mathrm{z}$ předkognitivního pohroužení do věcí. Z poukazu na to, že „zprvu a většinou“ zvládáme naše bytí ve světě díky netematickému obstarávání př́ručního jsoucna, totiž nelze vyvodit, že veškerá srozumitelnost je pouhým derivátem tohoto primárního modu existence. Zároveň s tím se ukázalo, že problém

\footnotetext{
${ }^{40}$ Heidegger (1996, s. 215).
} 
vzájemného poměru praxe a teorie zdaleka nelze řešit na rovině čistě epistemologické, nebot' sám rozdíl praktického a teoretického chování je nutno vyložit jejich hlubším ontologickým založením v bytí pobytu. Skutečně kritická reflexe tradiční opozice praktického a teoretického zaměření tedy nemůže vyústit v pouhé převrácení jejich původních hierarchických pozic, ale v prokázání jejich existenciální geneze v oné fundamentální nelhostejnosti pobytu k vlastnímu bytí, kterou Heidegger charakterizuje jako starost.

Druhá část této stati proto nejprve směřuje $\mathrm{k}$ ontologickému ukotvení pojmu praxe v souvislosti se sebe-porozuměním pobytu, načež analyzuje bytí věcí samých coby pragmat a končí důrazem na neodvoditelnost pojmu světa jako takového z pragmaticky artikulovaného pojmu okolí. Stojí za povšimnutí, že většina kritických poznámek, které zde byly předestřeny vůči interpretacím Marka Okrenta a Huberta Dreyfuse, se týkala zejména těch částí Heideggerovy fundamentální ontologie, které se samy vyznačují jistou nevyjasněností či nedořečeností. Nemožnost pojmout původní vztah k přírodnímu jsoucnu výhradně modelem obstarávání tak odkazoval na dvouznačnost Heideggerovy úvahy, která vedle využitelnosti lesa, kamene a větru na jedné straně a jejich objektivizace v přírodovědě na straně druhé naznačuje - aniž by ji rozváděla - třetí možnost odkrytí přírody, nakolik s ní instinktivně či emocionálně souzníme. Že tento poukaz zůstává v Bytí a čas nerozvinut, lze patrně přisuzovat tomu, že uznání svébytnosti fenoménu přírody - v její moci a neredukovatelnosti na zásobárnu zdrojů a energií či na hmotu v pohybu - by narušilo ono známé a zdánlivě samozřejmé dělení věcí na jsoucna příruční či výskytová. Také předestřené nedostatky Okrentova vymezení světa coby nejobecnější souvislosti funkčních poukazů lze do jisté míry přičíst na účet jisté nejasnosti, s níž Heidegger v § 16 začíná analýzu „světskosti“ analýzou světového rázu našeho okolí, aby později v $\$ 40$ radikálně proměnil význam, v jakém se ohlašuje svět jako takový. Pragmatická interpretace, charakterizující pojem světa na základě paradigmatu dílny, zprvu přehlížené a ve své naléhavosti posléze odkryté, by v tomto ohledu byla přípustná pouze za podmínky, že zruší Heideggerovo rozlišení mezi světem a okolím, respektive prokáže, že pouze o světě našeho okolí lze oprávněně mluvit, zatímco fenomén „světa v jeho světskosti““ je fenomenologicky nevykazatelný. K tomu by však bylo třeba předestřít explicitní kritiku Heideggerova rozvrhu, kterou v souvislosti s pojmem světa Okrent ani Dreyfus nepodávají. Teze o primátu praxe, na jejíž jednostrannost jsme se zde snažili poukázat, tak ve svém rozvedení do důsledků nakonec poukazuje na některé vnitřní kontradikce Heideggerovy ontologie, jejichž výslovnému uchopení bude třeba věnovat další samostatnou analýzu.

\section{Literatura}

Blattner, W. (2007): „Ontology, the A Priori, and the Primacy of Practice: An Aporia in Heidegger's Early Philosophy." In Heidegger's Transcendentalism, eds. S. Crowell \& J. Malpas, Stanford University Press, Palo Alto, 2007, s. 10-27.

Brandom, R. (2002): Tales of the Mighty Dead: Historical Essays in the Metaphysics of 
Intentionality. Harvard University Press, Cambridge.

Crowell, S. (2013): Normativity and Phenomenology in Husserl and Heidegger. Cambridge University Press, Cambridge.

Dreyfus, H. (1993): „Heidegger's Critique of the Husserl/Searle Account of Intentionality.“ Social Research 60: 17-38.

Haugeland, J. (2013): Dasein Disclosed: John Haugeland's Heidegger, ed. J. Rouse, Harvard University Press, Cambridge.

Heidegger, M. (1996): Bytí a čas. OIKOYMENH, Praha.

Heidegger, M. (1995): Ontologie. Hermeneutik der Faktizität. Gesamtausgabe Band 63.

Vittorio Klostermann, Frankfurt am Main.

Heidegger, M. (2004): Kant a problém metafyziky. Filosofie, Praha.

Husserl, E. (2010): Logická zkoumání. II/l, Zkoumání k fenomenologii a teorii poznání. OIKOYMENH, Praha.

Locke, J. (1984): Esej o lidském rozumu. Svoboda, Praha.

Okrent, M. (1988): Heidegger's Pragmatism: Understanding, Being, and the Critique of Metaphysics. Cornell University Press, Ithaca.

Okrent, M. (2000): „Intending the Intender (Or, Why Heidegger Isn’t Davidson).“ In Wrathall \& Malpas (2000): 279-301.

Rorty, R. (1991): „Heidegger, Contingency, and Pragmatism.“ In Essays on Heidegger and Others Philosophical Papers Volume 2., R. Rorty, Cambridge University Press, Cambridge, 1991, s. 27-49.

Rorty, R. (2012): Filosofie a zrcadlo př́rody. Academia, Praha.

Searle, J. (1983): Intentionality: An Essay in the Philosophy of Mind. Cambridge University Press, Cambridge.

Wrathall, M. \& Malpas, J., eds. (2000): Heidegger, Authenticity, and Modernity: Essays in Honor of Hubert L. Dreyfus. Vol. 1, The MIT Press, Cambridge, MA. 